RODOLFO VÁZQUEZ

\title{
Génesis del logos en Séneca, Filón, Justino y Tertuliano
}

7 AL vez una de las constantes más claras en el antiguo pensamiento pagano y|judeo-cristiano haya sido el tema del logos. El propósito de este artículo es aclarar en líneas generales su desarrollo histórico y ciertos aspectos doctrinales.

La selección de autores obedece, por tanto, a un criterio cronológico, pero sobre todo a un deseo expreso de mostrar a través de cada uno la génesis o la evolución doctrinal de la idea de logos, desde una posición pagana como la estoica hasta una cristiana como la de san Justino y Tertuliano, pasando por la visión judeo-helenística de Filón. Cada uno, a nuestro juicio, sintetiza el pensamiento antiguo en los tres primeros siglos de la era cristiana, periodo que en los últimos decenios ha sido objeto de numerosos estudios y del cual no es exagerado afirmar que constituye un pilar fundamental de la cultura occidental.

\section{Séneca y el estoicismo}

Unos años más joven que Filón, Séneca representa al estoicismo nuevo, imperial o romano por su localización, que se caracteriza por un abandono creciente de los planteamientos lógicos y físicos y por una dedicación clara a las cuestiones morales acorde con el espíritu práctico de los romanos.

Nacido en Córdoba el año 4 a.C., recibe su educación en Roma, siempre cerca de la alta aristocracia imperial: Ya célebre cae en desgracia ante Mesalina, primera esposa de Claudio, y es exiliado a Córcega. En el 49 d. C. es llamado a la corte de 
Claudio y Agripina, la segunda mujer de éste, le confía la educación de Nerón. Implicado en la conjura de Pisón, muere por orden del emperador abriéndose las venas el año 65 .

De las muchas cartas que Séneca dirigió a Lucilio, la número LXV, que lleva por título "De la causa primera", es tal vez de las más claras en cuanto a su concepción del logos.

Después de un breve preámbulo, Séneca explica a Lucilio la doctrina estoica sobre los diversos tipos de causalidad:

Dicen nuestros estoicos, como tú sabes, que hay dos cosas en la naturaleza de las que todo se hace: la causa y la materia. La materia yace inerte, preparada para todo, ociosa si nadie la mueve. Por el contrario, la causa, esto es, la razón [ ratio-logos], da la forma a la materia, la vuelve a lo que quiere y de ella saca varias obras. Debe, pues, haber de donde se haga algo y después quién lo haga. Esto es la causa; aquello la materia.

Para los estoicos, por lo que puede leerse, todas las cosas constan de "aquello que se hace" y de "aquello que lo hace". Esto último, en sentido estricto, es lo único que puede concebirse como causa.

En seguida, Séneca pasa a comparar esta doctrina con la de las escuelas tradicionales. Para Aristóteles:

La primera causa es la materia, sin la cual nada puede ser hecho; la segunda es el agente. La tercera es la forma que se imprime a cada obra, como la estatua; a ésta la llama eidos. Todavía se añade una cuarta: el fin de toda obra.

Por lo que respecta a Platón, Séneca descubre cinco tipos de causas, las cuatro aristotélicas y una quinta, la ejemplar, que Platón llama "idea":

[...]ésta [refiriéndose a la ejemplar] es a lo que mira el artista para hacer lo que se proponía. Nada importa si el ejemplar está por fuera, y a él vuelve los ojos, o por dentro, concebido y puesto por él mismo. Dios tiene dentro de sí estos ejemplares de todas las cosas y abarca con su mente el número y la medida de todo lo que ha de hacerse; está lleno de estas figuras que Platón llama los inmortales, inagotables ideas [...] Son, pues, cinco las causas como Platón dice: aquello de lo que (id ex quo); aquello por lo 
que (id a quo); aquello en lo que (id in quo); aquello conforme a lo que (id ad quod); y aquello para lo que (id propter quod).

Al revisar la doctrina tradicional, Séneca termina por cuestionarse si toda esta multiplicación de causas para explicar la realidad en verdad comprenden demasiado o, por el contrario, comprenden muy poco. Si por causa se está entendiendo tanto en Platón como en Aristóteles todo aquello sin lo cual no puede hacerse algo, son pocas las que dicen. En tal caso, tendrían que poner el tiempo, el lugar, el movimiento, etc. Si por causa se entiende la causa'primera y general, no debemos afirmar más que una, la razón, de la cual todas dependen. Porque si nos referimos a la forma, ésta es parte de la causa, pero no es la causa; si nos referimos a la causa ejemplar, ésta no es más que un instrumento del que se vale la causa; y si hablamos del fin, ésta es una causa accesoria pero no eficiente.

En síntesis, regresando a la postura inicial, Séneca concluye:

[...] todas las cosas son hechas de la materia y de Dios. Dios las gobierna, y rodeándolo le siguen como a su rector y guía. Pero quien hace, que es Dios, es más poderoso y más excelente que la materia, que recibe la operación de Dios. El lugar que Dios tiene en este mundo, lo tiene el alma en el hombre. Lo que es allí la materia, es en nosotros el cuerpo; que sirvan, pues, los peores a los mejores.

Dos siglos más tarde, Diógenes Laercio recuerda y nos confirma esta doctrina:

Según los estoicos, se dan dos principios en el universo: el principio agente (activo) y el principio paciente (pasivo). El

1 No deja de llamar la atención que Séneca, como hacía notar Fernando Sodi ("Metafísica de la causalidad", apuntes personales), interprete a Platón haciéndoie decir que el mundo de las ideas se encuentra contenidoen la esencia divina, cuandoen el Timeo, Platón separa claramente al demiurgo de los modelos ejemplares. Esta interpretación permite suponer con algún fundamento que Séneca constituye uno de los eslabones necesarios entre Platón y el neoplatonismo y a través de este con san Agustín. para quien las ideas ejemplares se hallan contenidas en la esencia divina. Por otra parte. es muy probable que la unidad substancial del logos con el Padre, que ya se afirma en Tertuliano, se haya inspirado en la unidad de naturaleza entre las ideas arquetipo y Dios que aparece en Séneca. 
paciente es la substancia sin cualidad, la materia; el principio agente es la razón, el logos, que está en ella, Dios, porque Dios, que es eterno, organiza cada cosa mediante la materia. ${ }^{2}$

Así pues, tenemos por un lado la materia (idex quo) y por otro el logos, razón o Dios (id a quo): principio pasivo y principio activo.

Por otra parte, según nos refiere el mismo Diógenes Laercio:

Llaman naturaleza tanto a lo que contiene el mundo como a lo que produce las cosas terrestres. La naturaleza es una manera de ser que se mueve por sí misma según razones seminales produciendo y conteniendo las cosas que en ella hacen a tiempos definidos y formando cosas semejantes a aquellas de las que se separó. ${ }^{3}$

El logos, entonces, gobierna y ordena la materia, no como principio extrínseco a la misma sino como principio intrínseco, produciend o y conteniend o las cosas que nacen en la naturaleza según "razones seminales". El logos aparece como razón espermática (spermatikós logos). ${ }^{4}$

Sin embargo, este logos spermatikós debe comprenderse en el contexto de la física estoica materialista: el mundo todo no tiene más que cuerpos y dado que todo es materia, todo en el mundo constituye una unidad. Todo está en todo en armonía universal, así, el mismo logos humano no es sino un fragmento de la razón cósmica. Coherente con este materialismo, el estoicismo resalta la doctrina sobre las "nociones comunes", que Crisipo sistematizó en la Stoa antigua y que, nuevamente, ejercerá una notable influencia en Tertuliano, a través de Séneca, Seneca noster, como le llamaba el africano.

Las nociones comunes son aquellas nociones propias del sentido común. Estas nociones se forman a temprana edad y el

2 Diógenes Laercio, Vida de los hombres ilustres, VII, 134.

3 Ibid., vII, 148.

4 La doctrina estoica del logos spermatikós aparecerá, nuevamente, con más o menos modificaciones, en Filón, en Justino, en el platonismo medio, en Tertuliano, en Plotino y a través de éste llegará a san Agustín y hasta san Buenaventura. 
niño ya las posee todas a los 14 años, aproximadamente. No son ideas innatas sino que nacen de la experiencia sensible y de acuerdo a su razonamiento natural. Constituyen la materia fundamental para una lógica concreta y vital, no abstracta y desencarnada. Así, por ejemplo, bastaría observar el orden del universo y familiarizarse con él para tener la noción de un dios ordenador. El hombre que negara a Dios sería un insensato, un apasionado al que le faltaría esa razón natural necesaria para la sabiduría. La noción de Dios se obtiene así por un conocimiento empírico, opuesto al conocimiento conceptual-filosófico.

En síntesis, podemos llegar a las siguientes ideas:

- para Séneca, y en general para los estoicos, sólo existen dos causas que explican la realidad de las cosas: ex quo (materia) y $a$ quo (logos); la causa a quo no es causa eficiente en sentido estricto, puesto que supone la materia preexistente. Más bien se trata de una causa generadora o motriz; causa movens pero no eficiens;

- la causa a quo, el logos, está en la materia, organizándola a través de las razones seminales. La inherencia de este logos spermatikós nos permite concluir en un monismo materialista, en el cual la misma razón humana no es sino parte del logos universal; por último,

-en coherencia con tal materialismo, la lógica concreta se funda sobre "nociones comunes" obtenidas por experiencia sensible.

\section{Filón de Alejandría}

La vida y el pensamiento de Filón se ubican en la encrucijada de tres tradiciones culturales que aparecerán una y otra vez en sus obras: el helenismo, el legalismo romano y la fe judía.

Nacido hacia el año 20 a.C. en el seno de una familia judía acomodada, su formación quedará sellada tanto por el judaísmo propio de la diáspora, que en el caso de Filón, se complementa con una admiración profunda hacia el ideal moral de los esenios, así como por el hecho de haber nacidoen el centro de la cultura griega: Alejandría. A la xenofobia y al orgullo nacional, propios del judaísmo en Palestina, Filón 
opone un verdadero espíritu universal. Como señala Daniélou: "Su lengua es el griego. Su ciudad el imperio romano".5

$\mathrm{Su}$ originalidad radica en reformar la filosofía griega tradicional adaptándola a las exigencias de la Palabra de Dios y en su preocupación por presentar a los griegos la fe judía de tal forma que les resulte aceptable. "Su a mbición es precisamente unir la religión de Israel, la cultura griega, la ciudadanía romana. Equivalía a intentar en favor del judaísmo lo que el cristianismo realizaría cuatro siglos más tarde". ${ }^{6}$ Crear $\mid y$ expandir toda una civilización judía, es una empresa cuyo espíritu será asimilado por las escuelas y los pensadores cristianos que de una u otra forma bebieron de su pensamiento: apologistas como san Justino, o más directamente, los alejandrinos Clemente y Orígenes y, a través de éstos, los cristianos del siglo IV.

Designado jefe de una delegación de judíos de Alejandría para aclarar ciertos problemas de éstos ante Roma, siendo emperador Calígula, se embarcó y permaneció en esta ciudad durante un tiempo. Se sabe de su regreso exitoso a Alejandría a fines del 41 d.C., pero se desconoce la fecha de su muerte.

Formado dentro de los esquemas de la filosofía griega helenística, su posición, para algunos ecléctica, parece inclinarse a un estoicismo abierto a las influencias platónicas, tal como se manifestaron en Posidonio y en un contemporáneo de éste, Antíoco de Ascalón, en el siglo I a.C. Este carácter platónico de su pensamiento, unido a su formación hebrea, le permitirá partir de ciertos supuestos distintos al de los estoicos, que darán a su doctrina sobre el logos un matiz especial.

En primer lugar, a diferencia de los estoicos, el logos en Filón será entendido dentro de un marco espiritual, como razón inmaterial más que como razón material cósmica.

Por otro lado, como veremos en seguida, el logos se comprenderá ahora como una realidad distinta e inferior que "participa"de la razón divina. Situación ajena a un estoico, pero no a un platónico desde el momento mismo en que éstos

\footnotetext{
5 Jean Daniélou, Ensaỵo sobre Filón de Alejandria, Taurus, Madrid 1962.

6 Ibid., pp. 26-27.
} 
piensan, desde Platón, en una realidad superior, única e incomprensible. ${ }^{7}$

Por último, Dios se da a conocer a sí mismo por una suerte de acción interior en elalma a través del logos spermatikós. Esta suerte de iluminación espiritual le permitirá referirse a los spermata en un sentido inmaterial y no material como en los estoicos.

Todas estas ideas influirán de manera decisiva en el platonismo medio posterior a Filón: Plutarco (m. 125), Numenio (m. 150) y Albino (m. 180).

Filón comienza por sentar la absoluta trascendencia de la naturaleza divina. Esto supone, inmediatamente, la incomprehensibilidad de Dios. Dios es el todo otro: "Dios está solitario, separado, porque es único y nada semejante a Él”. Es increado, no se parece en nada a las cosas creadas sino que las trasciende tan completamente que incluso la inteligencia más penetrante está muy lejos de aprehenderle y debe confesar su impotencia. Por hallarse encerrada dentro de las categorías de espacio y tiempo, la inteligencia no puede aprehender la ousía divina.

Con estas ideas, Filón se presenta como el gran precursor de la teología negativa que tan grande influencia ejercerá en las escuelas posteriores: en el neoplatonismo, en la escuela de Alejandría y, a través de ésta, en los capadocios, especialmente en san Gregorio de Nisa.

Sin embargo, si bien la esencia divina es incomprehensible, no se sigue que no podamos conocer nada de Dios. Y es aquí, precisamente, donde aparece el papel mediador del logos. Según Daniélou:

No hay ningún otro aspecto del pensamiento de Filón que no haya sido estudiado tanto. Es imposible, en efecto, hacer la exégesis del capítulo I de san Juan o estudiar los orígenes del dogma de la Trinidad sin encontrarse con ella. Hay que añadir también que tampoco hay otra que siga siendo tan oscura. Se discute sobre los orígenes de la doctrina: sus relaciones con las la esencia.

7 Véase Platón, República, libro VI, donde sitúa al bien por encima del ser y de 
especulaciones rabínicas sobre la Memra o las concepciones griegas de la razón inmanente. ${ }^{8}$

El logos, afirma Filón, es el más antiguo de los seres; es el hijo primogénito de Dios; es la imagen de éste. El logos, sin embargo, es inferior a Dios, se halla en la frontera que separa la creación de lo creado. No es ingénito como el Padre, ni engendrado como nosotros, sino intermedio entre los dos extremos:

Al logos arcángel y muy antiguo es a quien el Padre que lo ha engendrado todo ha hecho el don insigne de estar situado en la frontera para separar la creación del Creador. Intercede sin cesar cerca del incorruptible por la naturaleza mortal y frágil y es enviado por el Señor al servidor. No es ingénito como Dios, ni engendrado como nosotros, sino intermedio entre dos extremos, y comunica con el uno y con el otro. ${ }^{9}$

El mismo logos es obra del Padre. Éste ha creado todo primero en su logos, que lo contiene todo y a través del cual llegará a la existencia. El logos es el principio de toda la creación inteligible y sensible. Es arquetipo (nous) en cuanto encierra en sí las ideas ejemplares de todas las realidades: "El mundo de las ideas no podría tener otro lugar más que el logos divino". ${ }^{10}$

Este carácter instrumental del logos en relación al Padre aparece por primera vez en Filón, quien de esta forma abrirá las puertas a todas las teorías subordinacionistas posteriores. Es clara la relación de esta teoría con los defensores de la teología negativa. Tres razones muy ligadas entre sí pudieron orientar a Filón en esta dirección:

1. Salvar la unidad y simplicidad divinas.

2. Escapar a toda acusación de idolatría por su misma formación hebrea.

8 Daniélou, op. cit., pp. 181-182.

9 Ibid., pp. 183-184. No podemos dejar de mencionar aquí toda la tradición platónica en torno al eros y su mediación, tal como se manifiesta en el célebre discurso de Diótima. El eros es un demonio mediador entre Dios y los hombres. El logos mismo, en tanto participado en el hombre, no dejará de cumplir, para Filón, esta función mediadora.

10 Apud Daniélou, op. cit., p. 186. 
3. La distinción en Dios de su ousía antes delacto de creary de su ousía en el momento que decide crear.

Sea de ello lo que fuere, para Filón:

El mundo ha sido creado y es producido enteramente por una causa. El logos mismo del Creador es el sello (sphragis) por el que cada ser ha sido informado. Por eso, cada una de las criaturas posee desde el principio su forma (eidos) perfecta, por cuanto es la impronta y la imagen del logos perfecto."

De esta manera, a su carácter instrumental con respecto a la creación, se agrega ahora su carácter instrumental con respecto a la providencia. A través del logos, Dios crea y gobierna todas las cosas. La tradición hebrea y pagana se unen en Filón en una magistral síntesis judeo-helenística.

Sin embargo, si bien es cierto que su deuda hacia el estoicismo es fundamental para destacar el carácter providencial del logos, no lo es para explicar su constitución intrínseca. Entre Dios y el logos no se da una diferencia de atributos o de potencias. El logos no es una potencia divina sino una verdadera hipóstasis. Esto aparece desde el mómento mismo en que se concibe como palabra creadora (en hebreo dâbâr ), distinta al Padre como una densidad ontológica inferior que le permitirá cumplir con su función mediadora.

El carácter hipostático del logos será una consecuencia necesaria de su personificación, tal como se manifiesta en los escritos sapienciales. Esta personificación marca, definitivamente, una gran distinción con toda la tradición pagana, incluida la platónica. Tanto en Proverbios (8, 22-31), cuyo prólogo (1-9) fue escrito (siglo V a. C.) en época posterior al exilio, como en Sabiduría $(7,22-30 ; 8,1)$, cuyo autor es un judío helenizad o hacia el 50 a.C., se sigue una tradición que hace de la sabiduría o logos una hipóstasis, palabra creadora y por tanto personificada.

En síntesis, encontramos en el pensamiento de Filón queal logos spermatikós estoico se agrega ahora la idea del logos como palabra, no inmanente sino trascendente en tanto hipostático y personificado, pero inferior al Padre

11 Loc. cit. 
Por otra parte, como señalábamosal principio, a través del logos Dios se da a conocer a sí mismo por una acción interior en el alma. Esta iluminación espiritual se explica con la teoría estoica del logos spermatikós, si bien ya los spermata son entendidos inmaterialmente.

Será en este ambiente, donde confluyen ideas estoicas, judeo-helenísticas y un gnosticismo ya en gestación, que escribirá san Juan el prólogo a su Evangelio, aunque la originalidad de su doctrina, ya plenamente cristiana, supera con mucho las semejanzas con la tradición pagana y hebrea.

Entre Filón y san Justino media el Evangelio de san Juan.

\section{San Justino}

Con Justino nos encontramos, al decir de Quasten, con "una de las personalidades más nobles de la literatura cristiana primitiva". Nació en Palestina, en Pluvia Neápolis, la antigua Sichem. ${ }^{12}$

Según nos refiere el mismo Jusíno, conoció a los estoicos, luego a los peripatéticos, a un pitagórico y por último a un platónico (entendamos el platonismo medio). ${ }^{13}$ Un día hallóse con un anciano que logra comunicarle a través de un diálogo los inconvenientes filosóficos y le muestra la verdadera filosofía: "existieron hace mucho tiempo los profetas, los únicos que han anunciado la verdad". 14

La búsqueda de la verdad lo conduce al cristianismo: "la verdadera filosofía". Del texto anterior se desprende un punto importante para la comprensión de Justino: el ser testigo fidedigno de la verdad, como es el caso de los profetas, se halla por encima de toda demostración: "Porque no compararon jamás sus discursos con demostración, como quiera que ellos sean testigos fidedignos de la verdad por encima de toda demostración".15

12 Johannes Quasten, Patrologia, BAC, Madrid 1961, p. 190.

13 Apología, 2, 2.

14 Ibid., 8.

15 Loc. cit. 
El testimonio llega a ser una verdad más fundamental y existencial que la demostración:

- Y es así que yo mismo, cuando seguía la doctrina de Platón y oía las calumnias contra los cristianos, al ver como iban intrépidos a la muerte y a todo lo que se tiene por espantoso, me puse a reflexionar que era imposible que tales hombres vivieran en la maldad y en el amor a los placeres. ${ }^{16}$

Justino y seis compañeros más fueron decapitados, probablemente el año 165: había llegado a Roma durante el reinado de Antonino Pío. San Justino pertenece a esos pensadores cristianos del siglo II conocidos bajo el nombre de apologistas.

Al igual que Filón, san Justino comienza por sentar la total trascendencia e incomprehensibilidad de Dios:

Porque el Padre del universo, ingénito, como es, no tiene nombre impuesto, como quiera que todo aquello que lleva su nombre supone a otro más antiguo que se lo impuso. Los de Padre, Dios, Creador, Señor, Dueño, no son propiamente nombres, sino denominaciones tomadas de sus beneficios y de sus obras. La denominación Dios no es nombre, sino una concepción ingénita, en la naturaleza humana de una realidad inexplicable. ${ }^{17}$

Para Justino como para Filón, Dios es inefable, sin nombre, lo totalmente otro; y para salvar el abismo que media entre Dios y el hombre estructura su doctrina sobre el logos.

El logos es mediador entre Dios Padre y el mundo. Dios se comunica y se revela al mundo a través del logos.

El logos se ha engendrado en el interior de Dios. Mora en el interior (logos endiathetos) y antes de la creación del mundo emana y procede de Dios en vistas a la creación (logos prophori$k o ́ s)$. La distinción entre el verbo interior y la palabra proferida aplicada al $\log o s$, tal como es asimilada por Justino, se debe a la tradición estoica, si bien ya Platón y Aristóteles habían marcado tal distinción aunque no aplicada al logos: generación del

\footnotetext{
16 Apol., 2, 12.

17 Apol., 2, 5.
} 
verbo por el intelecto ( Fedro, 276s) yen Aristóteles la distinción noesis-noeseos. ${ }^{18}$

Sin embargo, esta procesión en el interior de Dios no escapa al peligro del subordinacionismo que ya habíamos encontrado en Filón: 19 el verbo se hizo externamente independiente con el fin de crear y gobernar el mundo. Viene a ser una hipóstasis por su función personal, con una densidad ontológica inferior a la de Dios.

Pero la doctrina del logos en Justino es cristiana. No en vano media entre Filón y Justino el pensamiento joánico:

En san Justino, todas las veces que Cristo es llamado logos y nomos como mediador de la divina revelación, lo hace dentro del contexto de la comprensión histórica de la revelación. De san Juan sacó su prueba de que la Palabra hecha carne es idéntica al logos preexistente, quien es también el mediador de la creación y de la revelación. Justino se preocupa de dar los datos históricos de la existencia terrenal del logos hecho carne (l Apol., 13,3). La Encarnación es el último eslabón de una cadena de apariciones históricas que tenían por objeto mostrar al Padre (Diál., 75, 4). La revelación del logos es un plan, la historia de la humanidad con su propósito, con su principio y con su fin. El logos es el centro del nuevo orden del mundo. 20

Este planteamiento con respecto al logos lleva a Justino a la necesidad de of recer un marco histórico más amplio y originala la providencia de los estoicos. ¿Se reveló Dios sólo a los judíos en la ley y los profetas? ¿Acaso se habría logrado el avance hecho en la historia por la mente griega en forma independiente del plan educativo de la divina providencia? Estas preguntas serán, entre otros, los temas centrales del sistema de Orígenes y alcanzarán su plena respuesta con san Agustín.

Ahora bien, pese al carácter cristiano del logos, Justino no se puede librar de la influencia del estoicismo y del logos spermatikós bajo la interpretación del platonismo medio: herejia arriana.

18 Luis Ramos, "El logos en Justino", artículo inédito.

19 Apol., 1, 13 y Apol., 11, 6. El subordinacionismo abrirá las puertas para la

20 Ramos, op. cit. 
Los' spermata son participaciones del logos en el espíritu humano. Es el resultado de la actividad del logos que siembra el conocimiento en la razón humana. Es el nivel ínfimodel conocimiento (conocimiento en sombras) que llega al summum solamente con la participación del logos. En donde hay sólo semillas del logos, éste sólo está presente en partes (apromeros). Ahora bien, el logos es la fuente del conocimiento parcial en todos los hombres. Así, los filosóf os antiguos que vivieron de acuerdo con el logos, participan del conocimiento del logos divino. Por eso dice Justino, quienes viven de acuerdo con el logos son cristianos, aunque sean judíos o bárbaros ( $1 \mathrm{Apol}$., 46, 1-4). Por ello se puede afirmar que los filósofos tomaron su conocimiento de Moisés, quien había recibido éste del logos (Cf. I Apol., 59, 1; $60,5-8) .{ }^{21}$

El cristianismo aparecerá, entonces, como la culminación de un plan universal de salvación. Lo que distingue al cristiano no es sólo la afirmación de un Dios creador y personal, sino la afirmación de Dios hecho carne: Dios encarnado. Esto es claro en Pablo y Juan, y como vemos ahora, en san Justino. El logoses Cristo hecho carne.

\section{Tertuliano}

Hijo de un centurión romano, nació en Cartago hacia el año 160 y estudió derecho en su ciudad natal, alcanzando una fama reconocida. Hacia el 195, influido por el testimonio de los mártires, se convierte al cristianismo y destaca como gran polemista y defensor de la fe que abrazaba. De esta época son dos de sus grandes obras: Apologético(197) y Sobre la prescripción de los herejes (200).

Posteriormente, se deja atraer por las tendencias más rigoristas dentro del cristianismo, en gran parte debido al mismo relajamiento moral y religioso de la iglesia y, finalmente, hacia el 207 se adhiere al montanismo que pretendía ser un cristianismo más purificado. Pese a la actitud poco moderada que distingue esta segunda etapa, escribe dos obras de gran

21 lbid. 
trascendencia: Sobre el alma (210-213) y Contra Praxeas(213), donde desarrolla sus ideas sobre la trinidad.

La importancia de Tertuliano en el desarrollo del cristianismo, tal como nos lo explica Daniélou, ${ }^{22}$ podemos verla desde tres aspectos de su vida: el literato, el jurista y el filósofo.

Tertuliano es un escritor latino, heredero de la cultura y de la literatura latina. Sin embargo, carente de una tradición cristiana latina, se sirve de los escritos de los padres griegos, tanto en su forma como en su contenido, para desarrollar su pensamiento. Es por ello que Tertuliano constituye un nexo capital entre el cristianismo griego y el cristianismo latino, aportando al ámbito la tino todas las controversias del siglo II. ${ }^{23}$

Además, es jurista y esto señala una profunda diferencia con la manera de argumentar de los a pologistas griegos. Las dos primeras partes del Apologético son una muestra de la sagacidad jurídica de Tertuliano. Así mismo, la prescripción, utilizando la autoridad de la iglesia como criterio de verdad, es uno de los argumentos que a partir de Tertuliano será característico del mundo latino. Tertuliano introduce también - y esto nos parece de suma importancia-, un vocabulario jurídico que será propio de la teología occidental y que la separa totalmente de la oriental. Dios aparece como el legislador que establece su ley y como juez que la aplica. El pecado es una violación de esa ley. El virtuoso será aquel que obre de acuerdo con la ley de la naturaleza y, en último término, con la ley de Dios. El logos en Tertuliano, a diferencia del de Justino, tendrá que enmarcarse en el ámbito propio de la ley y es probable que nuestras interpretaciones occidentales del logos griego hayan sido coloreadas por esta perspectiva legalista que introduce. Por ejemplo, la encarnación y redención (red-emo: re-comprar) de Cristo, responden a una deuda que se debe pagar.

Como filósofo encontramos en Tertuliano una marcada influencia estoica que, a diferencia de los apologistas griegos, para quienes el estoicismo era visto desde el platonismo medio, no pasa por este filtro sino que es asimilad o como fuente directa,

22 J. Daniélou y H. I. Marrou, Nueva Historia de la Iglesia, Cristiandad, Madrid 1964 , tomo l, pp. 193 y ss.

23 Ibid., p. 190. 
especialmente de Séneca. Este hecho separa, por ejemplo, la filosofía de un alejandrino como Clemente, de la de Tertuliano.

Podemos mencionar varios ejemplos que confirman lo anterior:

1. La noción de "natura" que permea todo el pensamiento estoico y que, como veremos al tratar del logos, es una de las nociones claves para su comprensión.

2. El materialismo estoico, cuando se refiere en De anima a la corporeidad del alma.

3. La prueba estoica de la divinidad a partir de las "nociones comunes".

Este último ejemplo presenta un gran interés para la comprensión de su pensamiento. Más que una confianza en la razón para demostrar a Dios, apela a la vía interior de las "nociones comunes". Así encontramos en Tertuliano una clara distinción entre lo que es un conocimiento natural de Dios por la vía de la experiencia personal, que es el auténtico conocimiento, del conocimiento por especulación filosófica. Este último no alcanza al Dios real. ${ }^{24}$

Debemos dejar claro que este rechazo de la razón no supone el rechazo de un conocimiento natural de Dios, sino de las conclusiones de los filósofos. El cristianismo será la culminación de un saber natural sobre Dios pero nada tiene que ver con la filosofía. Con esta aclaración es como hay que comprender este conocido texto de Tertuliano:

La filosofía es el objeto de la sabiduría mundana, intérprete temeraria del ser y de los designios de Dios. Todas las herejías tienen su origen en último término en la filosofía [...] De ella viene el Dios de Marción, cuya superioridad está en que está inactivo y es que procede del estoicismo. Hay quien dice que el alma es mortal, y ésta es doctrina de Epicuro [...] Los que equiparan a Dioscon la materia siguen las enseñanzas de Zenón. Los que pretenden un dios ígneo aducen a Heráclito [...] Es el miserable Aristóteles el que les ha insistido en la dialéctica, que es el arte de construir y destruir [...] de ella nacen[...] las disputas estériles [...] Pero, ¿qué tieneque ver Atenas con Jerusalén?¿Qué

24 Véase Richard Norris, God and World in Early Christian Theology, Adam \& Charles Black, London 1965, pp. 85 y ss. 
relación hay entre la academia y la iglesia? ¿Qué tienen que ver los herejes y los cristianos? [...] No tenemos necesidad de curiosear, una vez que vino Cristo, no hemos de investigar después del Evangelio. Creemos y nodeseamos nada más allá de la fe $[\ldots]^{25}$

La doctrina estoica de las "nociones comunes" abrió para Tertuliano otro acceso al conocimiento de Dios. Este acceso experimental e interior a Dios, unido al elemento jurídico del valor de la autoridad y a la tradición de la iglesia, será una de las características de la patrística latina, en especial de san Agustín, y a través de ésta de toda la teología medieval que en ella se inspira. ${ }^{26}$

Más adelante, Tertuliano aborda la cuestión que nos interesa, refiriéndose a la divinidad de Jesús:

Dejamos dicho que Dios creó el universo con su palabra, con su razón y con su poder. Nuestros mismos filósofos convienen en que el logos, esto es, la palabra einteligencia de Dios, es el artífice del universo. A Élatribuye Zenón la fuerza creadora, que ordenó todas las cosas, y lo llama el destino, el Dios, el alma de Júpiter, la necesidad de las cosas. Por su parte, Cleantes comprendía todos estos atributos en el espíritu, que supone embeber y penetrar todas las cosas.

También nosotros afirmamos que la verdadera sustancia del Verbo es ser espíritu, palabra, razón y poder de Dios, por el cual Dios ha creado todas las cosas: palabra, en todo lo que ordena; razón, en todo lo que dispone; y poder, en todo lo que ejecuta.

Creemos que Dios ha proferido esta palabra, el Verbo; que pronunciándolo, lo ha engendrado, y que por tanto se llama Hijo de Dios, y es Dios, porque tiene una misma sustancia con Él; porque Dios es espíritu.

A la manera de un rayo que brota del sol, es una porción del todo; pero el sol está en el rayo, porque es un rayo de sol; y no se opera en él una disgregación, sino una extensión de la sustancia:

25 Apud José Vives, Los Padres de la Iglesia, Herder, Barcelona 1971, pp. 364-365.

26 Véase Werner Jaeger, Cristianismo primitivo y paideia griega, FCE, México 1971, p. 53. "Los griegos siempre dan la bienvenida al apoyo de la razón, en tanto que la mente romana subraya siempre: 1) el factor de la personalidad en la aceptación de la fe cristiana; y 2) el factor suprapersonal de la autoridad." 
asi el Verbo que es espíritu de espíritu, Dios de Dios, como una luz que se enciende en otra luz. El manantial de la luz permanece entero e inmutable, aunque preste su luza muchos y se propague su esplendor. Del mismo modo, lo que procede de Dios es Dios, es hijo de Dios, sin dejar de ser ambos una sola substancia, espíritu que procede de espíritu, Dios que procede de Dios; diverso por sus propiedades, llega a serdistintoennúmero, pero no en su sustancia ni en su naturaleza; procede de un principio, sin separarse de él. ${ }^{27}$

En este texto se condensa toda la tradición con respecto al $\log o s$ anterior a Tertuliano y se añade algo original que se inspira en la unidad de naturaleza estoica: el Padre y el logos son una misma sustancia porque Dios es espíritu, si bien entre ambos existe una diferencia numérica.

Tertuliano será el primero en emplear el término de persona, otra vez bajo la influencia estoica, al referirse al Padre y al logos: "El logos es otro que el Padre en el sentido de persona, no de substancia, para distinción no para división". ${ }^{28}$

La persona se aplicará también al Espíritu Santo y así:

Son tres no por la cualidad sino por el orden; no por la substancia, sino por la forma, no por el poder, sino por el aspecto. Los tres tienen una sola naturaleza y un mismo poder, porque no hay más que un solo Dios y por razón del orden, la forma y el aspecto, se dan las designaciones de Padre, Hijo y Espíritu Santo, y aunque se distinguen en número, no por esto están divididos. ${ }^{29}$

$Y$ en el contexto de una tradición cristiana, al igual que Justino, afirma:

Este Verbo, o rayo de Dios, según estaba repetidas veces a nunciado en los pasados siglos, descendió al seno de una virgen para tomar carne mortal, y nació de ella Dios y hombre. La carne

\footnotetext{
27 Apologético, cap. XXI [las cursivas son nuestras ]

28 Quasten, op. cit., p. 604.

29 lbid.
} 
animada por el espíritu se nutre, crece, habla, enseña, obra, y ese es Cristo. ${ }^{30}$

Sin embargo, pese a esta unidad substancial entre el Padre y el logos, para ser justos debemos señalar que Tertuliano no logra librarse absolutamente de la influencia del subordinacionismo al mostrar como se genera el Verbo. La vieja distinción entre logos endiathetos y logos prophorikós, el Verbo interno o inmanente en Dios y el Verbo proferido por Dios que desvió a san Justino, induce también a Tertuliano a pensar que la generación divina se efectúa gradualmente. Como señala Quasten:

Sabiduría y Verbo son nombres idénticos para la Ségunda Persona, pero Tertuliano distingue entre el primer nacimiento en cuanto Sabiduría antes de la creación, y una nativitas perfecta al momento de la creación, cuando el logos fue proferido y la Sabiduría vino a ser el Verbo. El Verbo es engendradoen vistas a la acción. ${ }^{31}$

Nuevamente, Proverbios, 8, 27. Pese a ello, es indudable la aportación de Tertuliano a la génesis del logos. El estoicismo a través de Séneca se une en Tertuliano a la tradición de la patrística griega, para concluir en la afirmación de un logos no inferior al Padre sino en íntima unidad, con igual peso ontológico, aunque distintos como personas.

El logos hecho carne es la segunda persona de la Santísima Trinidad.

30 Apologético, cap. XXI.

31 Quasten, op. cit., pp. 604-605. 